\title{
ASSESSING THE ROLE OF EU AGENCIES IN THE ENLARGEMENT PROCESS: THE CASE OF THE EUROPEAN AVIATION SAFETY AGENCY
}

\author{
Florin Coman-Kund ${ }^{* *}$
}

Summary: This paper examines from a legal perspective the modes in which EU agencies partake in the enlargement process. In so doing, first the main forms in which agencies become involved in EU enlargement are explored. Next, EU agencies' forms of participation in the enlargement process are subjected to a legal assessment taking the principle of institutional balance and the delegation of powers within the EU as the main yardsticks. In this context, the legal nature of such forms of participation and related instruments are discussed, as are some of the relevant legal problems they might raise. The paper examines these issues both with regard to the wider category of EU agencies and by focusing on the European Aviation Safety Agency (EASA), an agency actively involved in the enlargement process, in order to provide a concrete illustration of how agencies' involvement works in practice. It is argued that, apart from the formalised cooperation instruments that could result in legally binding agreements under international law, the forms in which EU agencies take part in the enlargement process do not create insurmountable legal and practical problems. As for the more controversial category of 'binding agreements' concluded by EU agencies, objections can be raised in view of the rather conventional reading by the CJEU of the balance of powers between the EU institutions, in particular with regard to the Union's treaty-making. Arguments are advanced for an alternative route based on a dynamic interpretation of the institutional balance and of the delegation of powers within the EU.

\section{Introduction}

European Union agencies (EU agencies) have been set up as technical bodies engaged in operational functions and supporting decision-

\footnotetext{
* The author wishes to thank Andrea Ott for valuable comments on previous draft materials upon which this paper is based. Thanks are extended to the anonymous reviewer of this paper. The author is solely responsible for all remaining errors. The paper is based on official legal sources available until 22 June 2012. All websites were last accessed on 26 October 2012.

"* Doctoral researcher, Faculty of Law, Maastricht University, the Netherlands.
} 
making processes in various policy areas, such as aviation, food safety, environment, border control activities, police and judicial cooperation, as well as human rights. ${ }^{1}$ The ever expanding external dimension of these policy areas in the context of globalisation has prompted EU agencies to become active actors at the global level. ${ }^{2}$ First, in their field of expertise, these bodies are increasingly relating to relevant third countries and international organisations. Second, EU agencies are getting involved together with the Commission and the Council in the daily management of the Union's external relations. In this context, EU agencies are also involved in the EU enlargement process wherein they have established cooperative relations with candidate and potential candidate countries through various partnerships and technical assistance projects. Third, candidate and potential candidate countries can participate, in principle, in the work of EU agencies, while, at the same time, most of these bodies are involved in monitoring the implementation of the EU acquis by the candidates for EU membership. Such instruments and actions are to be seen as part of the wider efforts to prepare candidate and potential candidate countries for EU membership. In this domain, EU agencies contribute at a technical level to ensuring compatibility between EU standards and the standards of the candidate countries in various policy areas. They also arguably promote the exportation of EU regulatory standards to these countries as part of the acquis.

This paper aims to disentangle and examine from a legal perspective the different ways in which EU agencies contribute to the enlargement process, as well as the instruments they use to that effect. For this purpose, several steps will be taken. First, a general account of the EU agencies' role, tasks, and their developing international dimension will be given as part of the contextual framework for assessing their involvement in the EU enlargement process. Second, the paper will provide an overview of the main forms of involvement of the EU agencies in the enlargement process. Third, such forms of involvement, together with the relevant instruments and activities performed by EU agencies in the context of enlargement, will be subjected to a preliminary legal assessment. In this context, the paper will discuss the legal nature of the EU agencies' relevant instruments and some relevant legal problems that might arise from the use of some of these instruments from both an EU and an international law perspective. Finally, this analysis will focus on the European Aviation Safety Agency (EASA) as an example of an agen-

\footnotetext{
1 See E Vos 'Reforming the European Commission: What Role to Play for EU Agencies?' (2000) 37 CML Rev 1117-1118.

2 See A Ott, 'EU Regulatory Agencies in EU External Relations: Trapped in a Legal Minefield Between European and International Law' (2008) 13(4) European Foreign Affairs Review 515.
} 
cy actively involved in the enlargement process. The paper will reveal that, in principle, the EU agencies' actions and instruments performed in the context of enlargement seem legally acceptable under the EU legal framework. However, the lack of clarity surrounding the legal nature and effects of the EU agencies' formalised cooperative instruments (such as agreements, working arrangements or memoranda of understanding) raises concerns in view of the Union's principles of institutional balance and delegation of powers.

\section{EU Agencies as elements of the Union's institutional framework featuring a global profile}

EU agencies have become a well-established and at the same time quite a debated component of the institutional structure of the European Union. A significant number of agencies operate at the EU level and probably more bodies of a similar nature will be established in the near future. The current reality has finally been acknowledged by the Treaty of Lisbon and, consequently, several references to 'agencies' are now scattered in the founding treaties. ${ }^{3}$ However, the founding treaties do not include horizontal provisions clarifying the legal status, tasks and powers of this category of EU bodies.

EU agencies have been created over time in miscellaneous areas of the Union's action, using different techniques and based on varied reasons and circumstances. ${ }^{4}$ While there is no consensus on the definition and ambit of the category 'EU agency', ${ }^{5}$ for the purpose of this paper, it encompasses the so-called 'regulatory' or the former 'Community' agencies and, after the depillarisation operated by the Treaty of Lisbon, the former third pillar agencies. ${ }^{6}$ Furthermore, there are some fluctuations

3 Express references to agencies can be found in arts 15, 16, 263 and 265 TFEU.

4 See Vos (n 1).

5 The Commission acknowledged that, in fact, '...there is no single model for a European agency...', but rather several models. See Commission (EC), 'The operating framework for the European Regulatory Agencies' (Communication) COM (2002) 718 final, 11 December 2002, 3. In this paper, the terms 'EU agency' and 'European agency' are used interchangeably.

6 See COM (2002) 718 final (n 5) 4; Commission (EC), 'Draft Interinstitutional Agreement on the operating framework of the European regulatory agencies' COM (2005) 59 final, 25 February 2005, 5 and 10-11. On the EU website, the label 'decentralised agencies' is currently used to designate the plethora of specialised EU bodies equipped with their own legal personality. See <http://europa.eu/agencies/regulatory_agencies_bodies/index_en.htm>. However, for the purpose of this paper, the EU agencies active under the Common Foreign and Security Policy (CFSP) are excluded because these bodies continue to operate under a rather (different) intergovernmental legal framework. The executive agencies set up on the basis of Council Regulation (EC) 58/2003 of 19 December 2002 laying down the statute for executive agencies to be entrusted with certain tasks in the management of Community programmes [2003] OJ L11/1 also remain outside the realm of this paper because they have quite a specific legal status in comparison with the 'regular' EU agencies. 
between agencies as concerns their formal tasks and powers, as well as their internal organisation and operation. This holds true also with regard to the relationships between EU agencies and other actors. ${ }^{7}$

Nevertheless, some general observations can be made with regard to the legal status of EU agencies on the basis of the relevant treaty provisions and policy documents regarding these bodies, their founding acts, and the daily institutional and legal practice. Thus, in spite of the existing differences, EU agencies seem to have been created mainly as technical or administrative components of the Union's 'executive branch'. ${ }^{8}$ Another feature of these bodies is that they are provided with some degree of formal autonomy. ${ }^{9}$ Their formal powers seem to be of a rather similar nature; thus, notwithstanding some exceptions, ${ }^{10} \mathrm{EU}$ agencies are entrusted mostly with administrative or technical prerogatives ancillary to decisionmaking. Related to this aspect, the principle of institutional balance has been advocated as one of the main legal obstacles precluding the European agencies from enjoying more significant formal powers. ${ }^{11}$

In practice, EU agencies are engaged in diverse forms of international relations with third countries and international organisations. ${ }^{12}$ In this context, one might attempt to distinguish several threads as concerns the international cooperation entered into by these bodies. ${ }^{13}$ First, most European agencies are involved in the management of the external

\footnotetext{
7 That is, EU institutions, relevant authorities and bodies from the Member States, actors outside the EU, stakeholders. See for more details on these issues E Vos, 'Agencies and the European Union' in L Verhey and T Zwart (eds), Agencies in European and Comparative Perspective (Intersentia 2003); E Chiti 'An Important Part of the EU's Institutional Machinery: Features, Problems and Perspectives of European Agencies' (2009) 46 CML Rev 1395.

8 See generally on the issue of EU executive power, P Craig 'European Governance: Executive and Administrative Powers Under the New Constitutional Settlement' (2005) 3 (2-3) I CON 407; D Curtin 'Executive Power of the European Union. Law, Practices, and the Living Constitution' in P Alston, G de Búrca, and B de Witte (eds), The Collected Courses of the Academy of European Law (volume XII/4, OUP 2009).

9 See M Groenleer, 'The Autonomy of European Union Agencies: A Comparative Study of Institutional Development' (DPhil thesis, Leiden University 2009) 100-110; and Vos (n 7).

10 For example the Office for Harmonization of the Internal Market (OHIM), European Aviation Safety Agency (EASA), Community Plant Variety Office (CPVO), European Chemicals Agency (ECHA). More specifically, these agencies are entrusted with limited powers to take decisions in individual cases: OHIM (registration of trademarks and designs); CPVO (grant of plant variety rights); EASA (issuance of certificates for aeronautical products); ECHA (registration of chemical products). See Commission (EC), 'European agencies - The way forward' (Communication) COM (2008) 135 final, 7; M Groenleer, 'The European Commission and Agencies' in D Spence (ed), The European Commission (John Harper Publishing 2006) 165; Chiti (n 7) 1404.

11 See Vos (n 7) 129-131.

12 See Ott (n 2) 518.

13 ibid 528.
} 
dimension of their respective policy area..$^{14}$ In particular, it appears that these bodies assist with technical and scientific support to the Commission and the Council, as well as to the Member States in their relations with international organisations and third countries. In this domain, some EU agencies assist the Commission in managing programmes with various third countries and also in the enlargement process wherein they provide technical assistance to candidate countries. ${ }^{15}$ Second, it

14 Such agencies are, for instance, EASA - see Article 27 of Regulation (EC) 216/2008 of the European Parliament and of the Council of 20 February 2008 on common rules in the field of civil aviation and establishing a European Aviation Safety Agency, and repealing Council Directive 91/670/EEC, Regulation (EC) No 1592/2002 and Directive 2004/36/EC [2008] OJ L79/1, as last amended by Regulation (EC) 1108/2009 of the European Parliament and the Council of 21 October 2009 amending Regulation (EC) No 216/2008 in the field of aerodromes, air traffic management and air navigation services and repealing Directive 2006/23/ EC [2009] OJ L309/51; European Medicines Agency (EMA) - see Articles 28c and 52 of Regulation (EC) 726/2004 of the European Parliament and of the Council of 31 March 2004 laying down Community procedures for the authorisation and supervision of medicinal products for human and veterinary use and establishing a European Medicines Agency [2004] OJ L136/1, as last amended by Regulation (EU) 1235/2010 of the European Parliament and of the Council of 15 December 2010 amending, as regards pharmacovigilance of medicinal products for human use, Regulation (EC) No 726/2004 laying down Community procedures for the authorisation and supervision of medicinal products for human and veterinary use and establishing a European Medicines Agency, and Regulation (EC) No 1394/2007 on advanced therapy medicinal products [2010] OJ L348/1; ECHA - see Article 77 of Regulation (EC) 1907/2006 of the European Parliament and of the Council of 18 December 2006 concerning the Registration, Evaluation, Authorisation and Restriction of Chemicals (REACH), establishing a European Chemicals Agency, amending Directive 1999/45/EC and repealing Council Regulation (EEC) No 793/93 and Commission Regulation (EC) No 1488/94 as well as Council Directive 76/769/EEC and Commission Directives 91/155/EEC, 93/67/EEC, 93/105/EC and 2000/21/EC [2006] OJ L396/1, as last amended by Commission Regulation (EU) 412/2012 of 15 May 2012 amending Annex XVII to Regulation (EC) No 1907/2006 of the European Parliament and of the Council on the Registration, Evaluation, Authorisation and Restriction of Chemicals (REACH) [2012] OJ L128/1; European Fisheries Control Agency (EFCA) - see Article 4 of Council Regulation (EC) 768/2005 of 26 April 2005 establishing a Community Fisheries Control Agency and amending Regulation (EEC) No 2847/93 establishing a control system applicable to the common fisheries policy [2005] OJ L128/1, as amended by Council Regulation (EC) 1224/2009 of 20 November 2009 establishing a Community control system for ensuring compliance with the rules of the common fisheries policy, amending Regulations (EC) No 847/96, (EC) No 2371/2002, (EC) No 811/2004, (EC) No 768/2005, (EC) No 2115/2005, (EC) No 2166/2005, (EC) No 388/2006, (EC) No 509/2007, (EC) No 676/2007, (EC) No 1098/2007, (EC) No 1300/2008, (EC) No $1342 / 2008$ and repealing Regulations (EEC) No 2847/93, (EC) No 1627/94 and (EC) No 1966/2006 [2009] OJ L343/1; Eurojust - see Article 26a of Council Decision 2002/187/ JHA of 28 February 2002 setting up Eurojust with a view to reinforcing the fight against serious crime [2002] OJ L63/1, as amended by Council Decision 2009/426/JHA of 16 December 2008 on the strengthening of Eurojust and amending Decision 2002/187/JHA setting up Eurojust with a view to reinforcing the fight against serious crime [2009] OJ L138/14; European Police Office (Europol) - see Article 23 of Council Decision 2009/371/JHA of 6 April 2009 establishing the European Police Office (Europol) [2009] OJ L121/37, etc.

15 For example EASA, European Centre for Disease Prevention and Control (ECDC), (European Food Safety Authority) EFSA, European Maritime Safety Agency (EMSA), European Railway Agency (ERA), ECHA, etc. See, for instance, Commission Implementing Decision of 18 July 2011 adopting the Multi-beneficiary Programme under the IPA Transition Assist- 
seems that the European agencies establish direct and autonomous formal and informal relations with third countries and international organisations. ${ }^{16}$ Third, it appears that third countries and sometimes also international organisations participate in various ways in the work of some EU agencies. ${ }^{17}$

As concerns the actions and instruments used by the EU agencies in their external relations, these range from simple exchanges of information, opinions, to memoranda of understanding, administrative arrangements and even agreements concluded with third countries and international organisations. ${ }^{18}$ Various sources ${ }^{19}$ provide more or less detailed information regarding the international practice of these bodies. Similarly, a closer look at the legal framework of the EU agencies reveals that in particular the founding acts of these bodies usually include provisions regarding cooperation with third countries and internation-

ance and Institution Building Component for the year 2011 - C(2011) 5117 final <http:// ec.europa.eu/enlargement/pdf/financial_assistance/ipa/2011/ipa_mbp_2011_c2011_ 5117_180711.pdf>.

16 For example EASA, Eurojust, Europol, European Agency for the Management of Operational Cooperation at the External Borders (Frontex), European Union Agency for Fundamental Rights (FRA), etc. Thus, in view of their legal framework (in particular, their founding acts) and practice, these agencies conclude in their own name international cooperation instruments, such as working arrangements (eg EASA and Frontex), administrative arrangements (eg FRA) memoranda of understanding (eg Europol - see Europol's press release 'Interpol and Europol Agree Joint Initiatives to Enhance Global Response against Transnational Crime' (12 October 2011) <https://www.europol.europa.eu/content/press/interpoland-europol-agree-joint-initiatives-enhance-global-response-against-transnati>), protocols (eg FRA - see the Protocol for Cooperation between UNDP and FRA <http://fra.europa. $\mathrm{eu} /$ fraWebsite/attachments/undp-fra-cooperation-agreement_EN.pdf>), and agreements (eg Europol, Eurojust, Cepol), and establish informal relations with relevant international actors.

17 Such agencies are EASA, European Environment Agency (EEA), European Agency for Health and Safety at Work (EU-OSHA), FRA, etc. This is documented inter alia by the EU agencies' founding acts. Thus, in the case of EASA and EEA, the participation of third countries in the respective agencies is explicitly stipulated. See Article 66 of Regulation 216/2008 (n 14) and Article 19 of Regulation (EC) 401/2009 of the European Parliament and of the Council of 23 April 2009 on the European Environment Agency and the European Environment Information and Observation Network [2009] OJ L126/13. As for EUOSHA and FRA, provision is made for the participation of both third countries and relevant international organisations in the work of these agencies. See Article 9 of Council Regulation (EC) 2062/94 of 18 July 1994 establishing a European Agency for Safety and Health at Work [1994] OJ L216/1, as last amended by Council Regulation (EC) 1112/2005 of 24 June 2005 amending Regulation (EC) No 2062/94 establishing a European Agency for Safety and Health at Work [2005] OJ L184/5, and Articles 9 and 28 of Council Regulation (EC) 168/2007 of 15 February 2007 establishing a European Union Agency for Fundamental Rights [2007] OJ L53/1.

18 See Ott (n 2).

19 Such as the EU agencies' websites, activity reports, annual programmes, evaluation reports, policy documents, etc. 
al organisations. ${ }^{20}$ Sometimes, such provisions are phrased in generic terms, ${ }^{21}$ while in other instances the relevant legal framework is more detailed in providing for specific international cooperation instruments to be used by the respective agency, the procedure for adopting such instruments, substantive limitations, and controlling mechanisms. ${ }^{22}$ The founding acts and other relevant legal instruments that are part of the EU agencies' legal framework, and in particular the provisions on international cooperation, bear special significance. Thus, they are to be seen as a source of the EU agencies' mandate to act on the international plane and, at the same time, as a tool for assessing the agencies' practice of international cooperation.

20 See Ott (n 2) 528-534. There are few exceptions, however, where the founding acts do not contain express provisions on international cooperation - ie CPVO, the Translation Centre for Bodies of the European Union (CdT), the Body of European Regulators for Electronic Communications (BEREC), and the Agency for the Cooperation of Energy Regulators (ACER). ACER is an apparent exception. Thus, Regulation (EU) 1227/2011 of the European Parliament and of the Council of 25 October 2011 on wholesale energy market integrity and transparency [2011] OJ L326/1, although without formally amending ACER's founding act, extends, nevertheless, the mandate of this agency and, within this extended mandate, it provides for international cooperation by this agency (Article 19).

${ }^{21}$ Such agencies are: the European Centre for the Development of Vocational Training (Cedefop) - see Article 3 of Regulation (EEC) 337/75 of the Council of 10 February 1975 establishing a European Centre for the Development of Vocational Training [1975] OJ L39/1, as amended by Council Regulation (EC) 2051/2004 of 25 October 2004 amending Regulation (EEC) No 337/75 establishing a European Centre for the Development of Vocational Training [2004] OJ L355/; the European Network and Information Security Agency (ENISA) - see Article 3 of Regulation (EC) 460/2004 of the European Parliament and of the Council of 10 March 2004 establishing the European Network and Information Security Agency [2004] OJ L77/1, as last amended by Regulation (EU) 580/2011 of the European Parliament and of the Council of 8 June 2011 amending Regulation (EC) No 460/2004 establishing the European Network and Information Security Agency as regards its duration [2011] OJ L165/3; EU-OSHA - see Article 3 of Council Regulation (EC) 2062/94 (n 17); the European Foundation for the Improvement of Living and Working Conditions (EUROFUND) - see Article 3 of Regulation (EEC) 1365/75 of the Council of 26 May 1975 on the creation of a European Foundation for the improvement of living and working conditions [1975] OJ L139/1, as last amended by Council Regulation (EC) 1111/2005 of 24 June 2005 amending Regulation (EEC) No 1365/75 on the creation of a European Foundation for the Improvement of Living and Working Conditions [2005] OJ L184/1, etc.

22 For example the European Police College (Cepol) - see Article 8 of Council Decision 2005/681/JHA of 20 September 2005 establishing the European Police College (CEPOL) and repealing Decision 2000/820/JHA [2005] OJ L256/63; EASA - see Article 27 of Regulation 218/2008 (n 14); Eurojust - see Articles 26a and 27a-27b of Council Decision 2002/187/ JHA (n 14); Europol - see Article 23 of Council Decision 2009/371/JHA (n 14); FRA - see Articles 6, 8-10 of Council Regulation (EC) 168/2007 (n 17); Frontex - see Articles 13-14 of Council Regulation (EC) 2007/2004 of 26 October 2004 establishing a European Agency for the Management of Operational Cooperation at the External Borders of the Member States of the European Union [2004] OJ L349/1, as last amended by Regulation (EU) 1168/2011 of the European Parliament and of the Council of 25 October 2011 amending Council Regulation (EC) No 2007/2004 establishing a European Agency for the Management of Operational Cooperation at the External Borders of the Member States of the European Union [2011] OJ L304/1; etc. 


\section{EU Agencies and the process of enlargement}

The process of enlargement is based on a very complex and comprehensive political, legal and financial framework. This is intended to ensure that both the states aspiring to EU membership and the EU itself are prepared for the accession of the former and for the post-accession phase. For candidate ${ }^{23}$ and potential candidate countries, ${ }^{24}$ accession to the European Union entails a gradual transformation of their political and institutional systems, as well as the adoption and implementation of the relevant acquis. ${ }^{25}$ The enlargement process requires permanent assistance and support from the Union to enable the countries aspiring to membership to meet the EU standards. ${ }^{26}$ It also entails a continuous monitoring process ensuring that each relevant country meets the conditions for accession. ${ }^{27}$ With regard specifically to the Western Balkan countries, for instance, the process of enlargement, also known as the 'Stabilisation and Association Process', comprises the following milestones: a Stabilisation and Association Agreement between each country and the EU; Accession or European Partnerships identifying in detail the duties of each country in terms of the acquis; Action Plans, as pragmatic instruments intended to ensure that the objectives set in the Accession Partnerships are met and to allow for close scrutiny. ${ }^{28}$ For the

23 Iceland, Montenegro, the Former Yugoslav Republic of Macedonia, Serbia, and Turkey, according to the information available on the official website of the European Commission in the section 'Enlargement' <http://ec.europa.eu/enlargement/countries/check-currentstatus/index_en.htm> last updated 26 October 2012. As from December 2011, Croatia is an acceding country. See, for instance, the European Commission's information note 'Signature of the Accession Treaty of the European Union (EU) with Croatia: Background Note' (MEMO/11/883, 9 December 2011) <http://europa.eu/rapid/press-release_MEMO11-883_en.htm>.

24 Albania, Bosnia and Herzegovina, and Kosovo (under UNSC Resolution 1244/99). See, for instance, the information available on the official website of the European Commission in the section 'Enlargement' <http://ec.europa.eu/enlargement/countries/check-currentstatus/index_en.htm> last updated 26 October 2012.

25 See M Maresceau 'Pre-accession' in M Cremona (ed) The Enlargement of the European Union (Collected Courses of the Academy of European Law, volume XII/ 1, OUP 2003).

${ }^{26}$ See MA Vachudova 'Strategies for Democratisation and European Integration in the Balkans' in Cremona (n 25).

27 See P Nicolaides 'Preparing for Accession to the European Union: How to Establish Capacity for Effective and Credible Application of EU Rules' in Cremona (n 25).

28 See European Commission 'Understanding Enlargement. The European Union's Enlargement Policy' (2011) 9-13 <http://ec.europa.eu/enlargement/pdf/publication/20110725_ understanding_enlargement_en.pdf>. For a detailed illustration of how this process works in practice, see Commission (EC), 'Enlargement Strategy and Main Challenges 2011-2012' (Communication) COM (2011) 666 final. See also J Marko and J Wilhelm 'Stabilisation and Association Agreements' in A Ott and K Inglis (eds), Handbook on European Enlargement (TMC Asser Press 2002) and M Spernbauer 'Benchmarking, Safeguard Clauses and Verification Mechanisms: What's in a Name? Recent Developments in Pre- and Post-Accession Conditionality and Compliance with EU law' (2007) 3 CYELP 292-294. 
whole of this process until the moment of accession, candidate countries are subjected to a monitoring process materialised inter alia in regular progress reports and strategy papers. ${ }^{29}$

Beside its political significance, the process of enlargement includes a technical dimension. The latter becomes visible in particular in the process of assisting candidate countries to meet detailed standards under various chapters of the acquis. It is also present in the process of monitoring the fulfilment of specific acquis duties and benchmarks by such countries. ${ }^{30}$ The European Commission is the main actor managing the accession process both in its political and technical dimensions. ${ }^{31}$ In this context, the Commission manages and implements various programmes and financial instruments in order to assist candidate and potential candidate countries on their way to EU membership. ${ }^{32}$ It is also responsible for the screening and monitoring of these countries, as well as for the required corrective measures. ${ }^{33}$

The EU agencies' involvement in the enlargement process is dependent on their position within the Union's institutional framework, on their role and tasks, as well as on the features of their respective policy area. Accordingly, EU agencies as auxiliary technical and administrative bodies would normally perform various tasks and activities of a technical nature in relation to candidate and potential candidate countries. These may include various forms of assistance with regard to the EU acquis, familiarising candidate and potential candidate countries about the way in which the Union's institutional and regulatory framework works, setting-up various forms of cooperation with the competent authorities from the relevant countries, monitoring and inspection tasks, etc. Below, an overview of some of the main modes in which EU agencies participate in the process of enlargement is presented to offer more concrete insight into the nature and breadth of their involvement.

One important form of involvement of EU agencies in the enlargement process consists of the participation of candidate and potential candidate countries in the work of these bodies. In this sense, it should

\footnotetext{
${ }_{29}$ See, for instance, European Commission 'Understanding Enlargement' (n 28); numerous progress reports and enlargement strategies are available for consultation on the official website of the European Commission, in the section dedicated to 'Enlargement' <http:// ec.europa.eu/enlargement/countries/strategy-and-progress-report/index_en.htm> last updated 22 October 2012. See also C Hillion 'The Copenhagen Criteria and their Progeny' in C Hillion (ed), EU Enlargement: A Legal Approach (Hart Publishing 2004) 13-14.

30 See Nicolaides (n 27).

31 Spernbauer (n 28) 293.

32 See, for instance, Commission (EC), 'Preparing for the participation of the Western Balkan countries in Community programmes and agencies' (Communication) COM (2003) 748 final.

33 See Spernbauer (n 28) 293-297.
} 
be pointed out that the founding acts of some EU agencies provide specifically for the involvement of candidates for EU membership in the particular agency. ${ }^{34}$ In other cases, the founding acts refer generally to the possibility of third countries participating in the agency. ${ }^{35}$ The founding acts often make effective participation in the relevant agency conditional upon the conclusion of agreements between the respective third countries and the EU, which are to include detailed rules for such participation. ${ }^{36}$

34 For example BEREC - Article 4 of Regulation (EC) 1211/2009 of the European Parliament and of the Council of 25 November 2009 establishing the Body of European Regulators for Electronic Communications (BEREC) and the Office [2009] OJ L337/1; European Asylum Support Office (EASO) - Article 49 of Regulation (EU) 439/2010 of the European Parliament and of the Council of 19 May 2010 establishing a European Asylum Support Office [2010] OJ 2010 L132/11 - with regard to Iceland; FRA - Article 28 of Council Regulation (EC) 168/2007 (n 17), referring specifically to the participation in the agency of candidate countries and countries with whom a Stabilisation and Association Agreement has been concluded.

35 For example ACER - Article 31 of Regulation (EC) 713/2009 of the European Parliament and of the Council of 13 July 2009 establishing an Agency for the Cooperation of Energy Regulators [2009] OJ L211/1; ECDC - Article 30 of Regulation (EC) 851/2004 of the European Parliament and of the Council of 21 April 2004 establishing a European Centre for disease prevention and control [2004] OJ L142/1; European Banking Authority (EBA) - Article 75 of Regulation (EU) 1093/2010 of the European Parliament and of the Council of 24 November 2010 establishing a European Supervisory Authority (European Banking Authority) [2010] OJ L331/12; ECHA - Article 106 of Regulation (EC) 1907/2006 (n 14); EEA - see Articles 8 and 19 of Regulation (EC) 401/2009 (n 17); EFSA - Article 49 of Regulation (EC) 178/2002 of the European Parliament and of the Council of 28 January 2002 laying down the general principles and requirements of food law, establishing the European Food Safety Authority and laying down procedures in matters of food safety [2002] OJ L31/1, as last amended by Regulation (EC) 596/2009 of the European Parliament and of the Council of 18 June 2009 adapting a number of instruments subject to the procedure referred to in Article 251 of the Treaty to Council Decision 1999/468/EC with regard to the regulatory procedure with scrutiny [2009] OJ L188/14; European Institute for Gender Equality (EIGE) - Article 19 of Regulation (EC) 1922/2006 of the European Parliament and of the Council of 20 December 2006 on establishing a European Institute for Gender Equality [2006] OJ L403/1; European Monitoring Centre for Drugs and Drug Addiction (EMCDDA) - Article 21 of Regulation (EC) 1920/2006 of the European Parliament and of the Council of 12 December 2006 on the European Monitoring Centre for Drugs and Drug Addiction (recast) [2006] OJ L376/1; European Training Foundation (ETF) - Article 23 of Regulation (EC) 1339/2008 of the European Parliament and of the Council of 16 December 2008 establishing a European Training Foundation (recast) [2008] OJ L354/82.

36 For example ACER - Article 31 of Regulation (EC) 713/2009 (n 35); EBA - Article 75 of Regulation (EU) 1093/2010 (n 35); ECDC - Article 30 of Regulation (EC) 851/2004 (n 35); ECHA - Article 106 of Regulation (EC) 1907/2006 (n 14); EEA - Article 19 of Regulation (EC) 401/2009 (n 17); EFSA - Article 49 of Regulation (EC) 178/2002 (n 35); EIGE - Article 19 of Regulation (EC) 1922/2006 (n 35); EMCDDA - Article 21 of Regulation (EC) 1920/2006 (n 35); ETF - Article 23 of Regulation (EC) 1339/2008 (n 35). This reality seems to match the Commission's view regarding the participation of candidate countries in individual EU agencies which proposes the conclusion of bilateral legal instruments for defining the details of such participation. See Commission (EC), 'Participation of candidate countries in Community programmes, agencies and committees' (Communication) COM (99) 710, 20 December 1999, 9. In this context, however, a two-step approach has been proposed: 1 . establish cooperation with the candidates for EU accession within the framework of EU relevant programmes in order to familiarise them with agencies' work; 2 . conclude agreements 
Participation of candidates and potential candidates in EU agencies may entail various forms, encompassing 'formative and informative' participation (seminars, joint working parties, special meetings after the meeting of the Management Board, etc), as well as participation in the management board of the agencies. ${ }^{37}$ Such participation is seen as a 'fundamental step' in ensuring the required familiarisation with the acquis. ${ }^{38}$ Hence, the Commission's suggestion that all candidates and potential candidates should participate in the work of all EU agencies before accession. ${ }^{39}$

In practice, one of the most obvious forms of involvement of candidate and potential candidate countries in EU agencies is participation in management boards. Two observations can be made with regard to this aspect. First, in spite of the rather similar provisions on third country participation in the founding acts of the EU agencies, the reality reveals a different picture. ${ }^{40}$ Thus, in many EU agencies, the participation of candidate and potential candidate countries in the management board is not officially activated or is only partially activated. This is the case for $\mathrm{EFSA}^{41}$ and the European Centre for Drugs and Drug Addiction (EMCDDA), ${ }^{42}$ whose management boards do not appear officially to include representatives of candidates for EU accession. On the other hand, the European Centre for Disease Prevention and Control (ECDC) ${ }^{43}$ and the European Agency for the Management of Operational Cooperation at the External Borders (Frontex) ${ }^{44}$ include only Iceland on the board, the

regarding the involvement of candidates for EU accession in the work of individual agencies. See COM (2003) 748 (n 32) 10.

37 COM (99) 710 (n 36) 9 and COM (2003) 748 (n 32) 9.

38 COM (99) 710 (n 36) 8.

39 ibid 9.

40 For more details regarding the reality of participation in EU agencies and the potential for the involvement of candidates for EU accession in individual agencies, see COM (99) 710 (n 36) 9 and COM (2003) 748 (n 32) 9. See also A Evans 'Institutions' in Ott and Inglis (n 28) 1067.

${ }^{41}$ See composition of the management board, European Food Safety Agency <http://www. efsa.europa.eu/en $/ \mathrm{mb} / \mathrm{mbmembers.htm> \text {. }}$

42 See EMCDDA's General Report of Activities 2011, 83-84 <http://www.emcdda.europa. eu/publications/general-report-of-activities/2011>. See also European Monitoring Centre for Drugs and Drug Addiction <http://www.emcdda.europa.eu/about/mb>.

43 See ECDC's Annual Report of the Director 2011, 58-59

<http://www.ecdc.europa.eu/en/aboutus/Key\%20Documents/1205-COR-Annual-reportDirector-2011.pdf $>$.

See also the composition of the management board, European Centre for Disease Prevention and Control <http://www.ecdc.europa.eu/en/aboutus/organisation/mb/Pages/AboutUs_ Organisation_ManagementBoard.aspx $>$.

44 See Frontex General Report 2010, 32-34

<http://frontex.europa.eu/assets/About_Frontex/Governance_documents/Annual_report/2010/frontex_general_report_2010.pdf $>$. See also Frontex General Report 2011, 37-40 
European Training Foundation $(\mathrm{ETF})^{45}$ has only Turkey on the governing board, while the management board of the European Environment Agency (EEA) ${ }^{46}$ includes only representatives of Iceland and Turkey. Second, when they participate in EU agencies, the representatives of these countries are usually given observer status, implying no voting rights on the board. ${ }^{47}$ Frontex might be an exception as it includes Iceland in the category of 'representatives of the management board', which is different from the status of 'invited participants' to the meetings of the board. ${ }^{48}$ An interesting situation concerns Turkey's participation in EMCDDA, based on an agreement concluded with the EU (not ratified yet). ${ }^{49}$ For the time being, it appears that Turkey's representative is participating as an observer at the heads of national focal point meetings. ${ }^{50}$ Finally, one should note that after signing the accession treaty, a candidate country acquires the status of 'acceding state'. Such a status entails, inter alia, becoming an 'active observer' in EU bodies and agencies, implying the right to speak, but not to participate in the adoption of the final decisions of the respective body or agency. ${ }^{51}$

A somewhat different dimension to the participation of potential candidate and candidate countries in EU agencies is furthered via support actions within the Instrument for Pre-Accession Assistance (IPA)

<http://www.frontex.europa.eu/assets/About_Frontex/Governance_documents/Annual_ report/2011/General_Report_2011.pdf>.

45 See the composition of the governing board, European Training Foundation $<$ http://etf. europa.eu/web.nsf/pages/Governing_board_members_EN>.

46 See EEA's Annual Report 2011 and Environmental Statement 2012, 77-78

$<\mathrm{http}$ //www.eea.europa.eu/publications/annual-report-2011>. See also the composition of the management board, European Environment Agency <http://www.eea.europa.eu/ about-us/governance/management-board/list-of-management-board-members>.

47 For example BEREC, EEA, ECDC, ETF.

48 This distinction was made in the Frontex General Report 2010 (n 44) 34. See also A Ott 'Turkey's Status in EU Institutions and Policies: Living in Sin or Living Separate Lives' in H Kabaalioglu, A Ott and A Tatham (eds), EU and Turkey: Bridging the Differences (Economic Development Foundation 2011) 133. It should be noted that such a delineation in the Frontex General Report 2011 is not formally operated anymore.

49 The agreement between the European Community and the Republic of Turkey on the participation of the Republic of Turkey in the work of the EMCDDA [2007] OJ L323/24 was officially signed by both parties on 30 October 2007 according to the section on partnerships with candidate and potential candidate countries on the official website of the European Monitoring Centre for Drugs and Drug Addiction <http://www.emcdda.europa. eu/about/partners/cc\#albania> last updated 4 September. See also Ott (n 48) 132.

50 According to the section on partnerships with candidate and potential candidate countries on the official website of the European Monitoring Centre for Drugs and Drug Addiction <http://www.emcdda.europa.eu/about/partners/cc> last updated 4 September 2012, and Turkey's country page available on the same website <http://www.emcdda.europa. eu/countries/turkey> last updated 24 September 2012.

51 See European Commission 'Understanding Enlargement' (n 28) 13. 
framework. In this context, the Commission manages inter alia projects on participation in EU agencies, entailing grants to these bodies in order for them to carry out various measures meant to facilitate the future participation of candidates for EU accession..$^{52}$ However, such actions performed by EU agencies are also part of the next form of involvement of these bodies in the enlargement process - ie technical assistance to candidate and potential candidate countries.

Another form of involvement of EU agencies in the enlargement process consists broadly of technical assistance and support actions in order to familiarise candidate and potential candidate countries with the EU acquis. ${ }^{53}$ Such assistance and support is provided by EU agencies under more or less formalised frameworks. An example of a more informal framework for cooperation with (the competent authorities of) candidates and potential candidates involving EU agencies and their staff is the Technical Assistance and Information Exchange Instrument (TAIEX). ${ }^{54}$ In this context, assistance in the transposition and enforcement of EU legislation is provided inter alia in the form of workshops, seminars, and training. ${ }^{55}$ Technical assistance and preparatory measures are or have been carried out by EU agencies also within more formalised technical and financial instruments encompassing until now several EU programmes under the Programme of Community Aid to the Countries of Central and Eastern Europe (PHARE) ${ }^{56}$ Community Assistance for Reconstruction, Development and Stabilisation (CARDS) ${ }^{57}$ and IPA. An illustrative example is the IPA Multi-beneficiary programme on preparatory measures for the participation of candidate and potential candidates in EU agencies first adopted in 2007, then again in 2009 and extended

52 See, for instance, Commission Implementing Decision of 18 July 2011 adopting the Multi-beneficiary Programme under the IPA Transition Assistance and Institution Building Component for the year 2011, C(2011) 5117 final (n 15) and, in particular, the Annex 'Multi-beneficiary Programme under the IPA Transition Assistance and Institution Building Component for the year 2011 '.

53 See Commission Implementing Decision of 18 July 2011 adopting the Multi-beneficiary Programme under the IPA Transition Assistance and Institution Building Component for the year 2011 (n 15), Project Fiche No 14 'Participation in EU Agencies' 2

$<$ http://ec.europa.eu/enlargement/pdf/financial_assistance/ipa/2011/pf_14_ipa_2011_ participation_in_eu_agencies.pdf $>$.

54 See, for instance, TAIEX Activity Report $2011<$ http://ec.europa.eu/enlargement/pdf/ taiex/11216_taiex_2011_en.pdf>. See also the information available on TAIEX on the official website of the European Commission <http://ec.europa.eu/enlargement/tenders/ taiex/index_en.htm> last updated 24 September 2012.

55 See, for instance, TAIEX Activity Report $2011<$ http://ec.europa.eu/enlargement/pdf/ taiex/11216_taiex_2011_en.pdf>. See also the information available on TAIEX on the official website of the European Commission <http://ec.europa.eu/enlargement/tenders/ taiex/index_en.htm> last updated 24 September 2012.

56 See COM (99) 710 (n 36).

57 See COM (2003) 748 final (n 32). 
in $2011 .{ }^{58}$ Such preparatory measures performed by EU agencies include providing advice on organisational matters, training the appropriate staff of candidates and potential candidates, as well as participation in specific events. To that effect, each EU agency ${ }^{59}$ involved in the project is awarded a grant by the Commission in order to organise and implement the required actions (ie training activities, study visits, workshops, conferences, outreach actions, etc) ${ }^{60}$ According to the Annex and the Project Fiche attached to the Commission's implementing decision, it becomes apparent that the Commission takes the relevant decisions (including those with financial implications) with regard to the projects carried out by the relevant EU agencies. ${ }^{61}$ On behalf of the beneficiaries, EU agencies contribute to the project description in cooperation with the beneficiaries, subject to the Commission's authorisation, and then implement the technical and support activities defined in those projects. ${ }^{62}$

A different form of participation in the enlargement process entails the involvement of EU agencies in the so-called 'benchmarking' of candidate and potential candidate countries. ${ }^{63}$ In this context, it transpires that most EU agencies are engaged in the monitoring of the implementation and enforcement of the EU acquis in their relevant policy areas. ${ }^{64}$ Such inspection and monitoring tasks performed by EU agencies are usually materialised in reports that are forwarded to the Commission. The findings of the EU agencies concerning alignment and compliance by candidates and potential candidates with the relevant EU standards in various policy sectors are eventually reflected or incorporated in the general progress reports and enlargement strategies issued regularly by the Commission. ${ }^{65}$

\footnotetext{
58 See Project Fiche No 14 (n 53) 3-5.

59 The programme focuses on thirteen EU agencies (CPVO; EASA; ECDC; ECHA; EEA; EFSA; EMCDDA; EMSA; ERA; EU-OSHA; EUROFOUND; EMEA; EIGE). See Annex to Commission Implementing Decision of 18 July 2011 adopting the Multi-beneficiary Programme under the IPA Transition Assistance and Institution Building Component for the year 2011 (n 52) 10, as well as Project Fiche No 14 (n 53) 4.

60 See, for an example, ECDC's Annual Report of the Director 2010, 32

$<$ http://ecdc.europa.eu/en/aboutus/Key\%20Documents/1106_COR_Annual_Report_Director_2010.pdf>.

61 See Project Fiche No 14 (n 53) 5.

62 See Project Fiche No 14 (n 53) 5. See, for an example of such a project implemented by EMCDDA < http://www.emcdda.europa.eu/html.cfm/index151216EN.html > last updated 18 September 2012.

63 See on the use of this term in the context of EU enlargement, Spernbauer (n 28) 281283.

64 See Project Fiche No 14 (n 53) 5.

65 See, for instance, Commission (EC) 'Bosnia and Herzegovina 2010 Progress Report accompanying the Communication from the Commission to the European Parliament and the Council 'Enlargement Strategy and Main Challenges 2010-2011' COM (2010) 660 final
} 
Yet another category of the EU agencies' actions relevant for the enlargement process consists of formalised cooperation instruments concluded by these bodies with candidate and potential candidates or with their competent authorities. Such instruments may bear different labels ${ }^{66}$ and they lay down a more general or specific framework for working relations between EU agencies and the countries aspiring to EU membership. Frontex, for instance, has concluded working arrangements with (the competent authorities of) Croatia, Montenegro, the Former Yugoslav Republic of Macedonia, Serbia, Albania, Bosnia and Herzegovina, and signed recently a memorandum of understanding with Turkey. ${ }^{67}$ In addition, Europol has an impressive record of operational and strategic agreements with all candidate and potential candidate countries, except for Kosovo. ${ }^{68}$ It should be noted that such formal arrangements could be conceived primarily as an instrument for the enlargement policy or, conversely, as an instrument aimed at promoting the external dimension of the sectoral policy that comes within the mandate of the agency, or both at the same time. In any case, such instruments are relevant in the enlargement process as they serve as yardsticks for assessing the progress made by each candidate and potential candidate with regard to specific chapters of the acquis. Such formalised instruments might mark a consolidated phase in cooperation between EU agencies and the countries aspiring to EU membership, illustrating advanced alignment with EU standards.

\section{EU Agencies' involvement in the enlargement process - a preliminary legal assessment}

\subsection{Legal yardsticks}

A legal assessment of the EU agencies' involvement in the enlargement process requires examining the legal nature of their various forms of participation and evaluating such participation against relevant legal

(Commission Staff Working Document) SEC (2010) 1331 final <http://eur-lex.europa.eu/ LexUriServ/LexUriServ.do?uri=SEC:2010:1331:FIN:EN:PDF $>$. This progress report includes information on developments regarding cooperation with Frontex (54). It also touches upon the way in which institutional cooperation with EMCDDA is progressing, and refers specifically to the information collection process as being in line with EMCDDA standards (57).

66 Such as 'working arrangements' (eg Frontex - see Article 14 of the Frontex founding regulation) or 'agreements' (eg Europol - see Article 23 of the Europol founding decision, and Eurojust - see Article 26a of Eurojust founding decision).

67 The memorandum of understanding between Frontex and Turkey was signed on 28 May 2012, according to the newsletter available on Frontex's official website <http://www. frontex.europa.eu/news/frontex-signs-a-memorandum-of-understanding-with-turkeyiY5Euj>.

68 Europol <https://www.europol.europa.eu/content/page/international-relations-31>. 
principles and standards. Within the Union context, the main yardsticks against which the EU agencies' performance should be assessed are the principle of institutional balance, as well as the doctrine of delegation/ conferment of powers. ${ }^{69}$ This is because over time one of the most troublesome issues has been the delegation or attribution of powers to EU agencies stemming from apparent fears not to disturb the Union's institutional balance. ${ }^{70}$ The assessment of EU agencies in view of these standards requires, on the one hand, establishing the nature and breadth of the powers that can be entrusted to EU agencies and, on the other hand, examining whether the EU agencies' activities and instruments remain within the scope of the mandate assigned to them.

The principle of institutional balance is rather aimed at a system of checks and balances in which the prerogatives of the EU institutions are guaranteed. ${ }^{71}$ The balance of powers does not imply an equal allocation of powers between the institutions, since this may vary significantly across policy areas and it changes over time. ${ }^{72}$ According to Majone, institutional balance requires 'that each institution: 1. has the necessary independence in exercising its powers; 2 . must respect the powers of the other institutions; 3. may not unconditionally assign its powers to other institutions and bodies'. ${ }^{73}$ In particular, the third observation made by Majone illustrates the relevance of the principle of institutional balance as regards the issue of delegation/conferment of powers to other bodies.

Because 'delegation of powers' is not defined in the Treaties, there is room for various interpretations of this concept, some narrower and some broader, leading to several 'delegation of power' scenarios within the EU. ${ }^{74}$ In one such scenario, an institution vested with certain powers

\footnotetext{
69 Also known as the Meroni doctrine after the Meroni cases (Case 9/56 Meroni \& Co, Industrie Metallurgiche SpA $v$ High Authority of the European Coal and Steel Community [1958] ECR 133 and Case 10/56 Meroni \& Co, Industrie Metallurgiche SpA v High Authority of the European Coal and Steel Community [1958] ECR 157) where issues of the delegation of powers and institutional balance were famously tackled by the Court of Justice. See also S Griller and A Orator 'Meroni Revisited: Empowering European Agencies between Efficiency and Legitimacy' (2007) NewGov 04/D40 <http://www.eu-newgov.org/database/DELIV/ D04D40_WP_Meroni_Revisited.pdf >.

70 See Vos (n 7) 129-131.

${ }^{71}$ S Prechal, 'Institutional Balance: A Fragile Principle with Uncertain Contents' in T Heukel, N Blokker, and M Brus (eds), The European Union after Amsterdam. A Legal Analysis (Kluwer Law International 1998) 280.

72 G Majone, 'Delegation of Regulatory Powers in a Mixed Polity' (2002) 8(3) European Law Journal 326; Prechal (n 71) 276.

73 Majone (n 72) 327.

74 See on this K Lenaerts 'Regulating the Regulatory Process: "Delegation of Powers" in the European Community' (1993) 18(1) EL Rev 23-49.
} 
transfers some of its prerogatives to another EU institution. ${ }^{75}$ In another scenario, powers are delegated by an institution to third parties. ${ }^{76}$ This particular scenario was at the origin of the Meroni doctrine established by the Court at the end of the 1950s. In the Meroni cases, ${ }^{77}$ the Court accepted, in principle, that EU institutions can delegate to external bodies executive powers that they themselves possess according to the Treaties, but only if such powers are 'clearly defined' and subject to their supervision. ${ }^{78}$ In yet another scenario, 'delegation' is understood in a broad sense whereby certain powers and tasks are entrusted to or conferred on other bodies by an institution (ie the legislator) which normally does not itself exercise such powers. In such a case, this is rather a conferment of powers on EU agencies than a 'mere' delegation of tasks.

Allegedly, the second and third 'delegation of powers' scenarios are relevant for EU agencies. The second scenario, entailing a typical delegation of powers, is apposite for EU agencies within the legal framework laid down by their founding acts. In this context, the Commission, in particular, delegates certain implementing tasks to EU agencies. ${ }^{79}$ Such delegation will abide by the standard Meroni requirements, as established in the CJEU case law. The third scenario is arguably applicable to EU 'regulatory' or 'decentralised' agencies since they are set up by legislative acts conferring on them certain (administrative) powers. ${ }^{80}$ One may wonder whether the delegation logic set by the CJEU in Meroni would apply mutatis mutandis in this particular context or whether conferring some powers becomes instead a matter of competence and ultimately an issue of institutional balance. ${ }^{81}$ By extrapolating the Meroni logic to this particular context, it can be maintained that the powers and tasks conferred on EU agencies do not affect the principle of institutional balance as long as such powers: 1 . are sufficiently defined and do not entail

\footnotetext{
75 See Lenaerts (n 74) 25-36.

76 Part or not of the Union's institutional framework.

77 Case 9/56 Meroni (n 69) 150-152 and Case 10/56 Meroni (n 69) 173. For an analysis, see E Vos, Institutional Frameworks of Community Health and Safety Legislation. Committees, Agencies and Private Bodies (Hart Publishing 1999) 201.

78 See Case 9/56 Meroni (n 69) 150-152.

79 For example, tasks are delegated to EU agencies in the context of the implementation of various EU programmes and in line with the EU Financial Regulation. See Council Regulation (EC, Euratom) 1605/2002 of 25 June 2002 on the Financial Regulation applicable to the general budget of the European Communities [2002] OJ L248/1 with the latest amendments, as well as Commission Regulation (EC, Euratom) 2342/2002 of 23 December 2002 laying down detailed rules for the implementation of Council Regulation (EC, Euratom) No $1605 / 2002$ on the Financial Regulation applicable to the general budget of the European Communities [2002] OJ L357/1 with the latest amendments.
}

80 See on this Griller and Orator (n 69).

81 See Lenaerts (n 74) 43; Vos (n 77) 203; Vos (n 7) 131-132. 
a significant degree of (political) discretion; 2. do not encroach upon the powers conferred by the founding treaties on EU institutions; 3. are subjected to sufficient supervision and controlling mechanisms. ${ }^{82}$ This test requires a close examination of the mandate of the EU agencies and of the accountability and control mechanisms designed by the founding acts and other relevant instruments. In performing this analysis, questions of compatibility with the EU founding treaties can occasionally be raised with regard to some of the powers bestowed on some agencies ${ }^{83}$ or in instances where the prerogatives of agencies are phrased in general and vague terms. In particular in the later case, one may wonder whether such prerogatives are sufficiently defined and would not entail a significant degree of discretion on behalf of the EU agencies.

Along with this test, it should be further investigated whether the EU agencies' actions and instruments remain within the realm of their mandate as established by their legal framework. This aspect could become particularly problematic when EU agencies exercise prerogatives that are stipulated in broad terms in their founding acts or when, in practice, these bodies perform actions and use specific instruments that are not explicitly provided for by their legal framework. However, from a functional perspective, such actions and instruments should remain, in principle, within the mandate of the agency as long as they are performed with a view to attaining the agency's mission and objectives. This approach would reflect an ERTA-type of reasoning whereby agencies' international cooperation prerogatives and instruments would be derived by way of necessary implication from their objectives and functions. ${ }^{84}$

\subsection{Assessing EU agencies' involvement in the enlargement process against the legal yardsticks}

The issue of the participation of candidate and potential candidate countries in EU agencies does not seem at first sight to raise difficulties in terms of institutional balance. As already mentioned, for most EU agencies the founding acts include explicit provisions on the participation of third countries in the work of these bodies. Furthermore, such participation is often dependent on agreements concluded between the EU and the third country concerned specifying the scope and conditions of third country involvement in the agency or allowing for detailed ar-

82 See Majone (n 72) 331; Vos (n 1) 1123. See also Griller and Orator (n 69).

83 For example the prerogative of Europol, Eurojust, and Cepol to conclude agreements with third countries and international organisations conferred explicitly on these bodies by their founding acts.

84 Cf Case 22/70 Commission v Council (European Agreement on Road Transport) [1971] ECR 263. 
rangements to be made to that effect. ${ }^{85}$ This suggests that EU agencies' respective tasks do not normally entail an excessive degree of discretion, nor do they encroach upon the powers of EU institutions, while their actions performed with a view to ensuring the participation of candidates and potential candidates are within the realm of their mandate.

However, the participation of candidate and potential candidate countries in the decision-making bodies of EU agencies, in particular in the management board, might seem problematic. This issue might arise under the standards set by the CJEU in the Opinions on the EEA agreement ${ }^{86}$ with regard to the participation of third countries in the decision-making of the Union's supranational institutions. ${ }^{87}$ In those Opinions, the Court stated the principle according to which it is possible to make arrangements by virtue of an agreement as to the sharing of the respective competences of the EU and third countries in a certain area, but only as far as such arrangements do not change the nature of the powers of EU institutions. ${ }^{88}$ One of the consequences derived from this principle is that third countries cannot participate in the decision-making of EU institutions ${ }^{89}$ where the outcome of the process would bear a different legal weight for the third country concerned as compared with the EU system..$^{90}$ This would actually amount to changing the nature of the powers of the Union's institutions.

Nevertheless, these concerns can be alleviated by the following two arguments. First, EU agencies are not part of the main EU supranational institutional framework, but separate bodies with very limited decision-making powers. ${ }^{91}$ This is relevant because a distinction may be made between the main EU institutions in which participation of third countries is, in principle, excluded and the other elements of the Union's institutional framework (including agencies) where participation seems to be allowed in practice. ${ }^{92}$ Second, candidate and potential candidates

\footnotetext{
85 See Ott (n 48) 132.

86 Opinion 1/91 Draft agreement between the Community, on the one hand, and the countries of the European Free Trade Association, on the other, relating to the creation of the European Economic Area [1991] ECR I-6079 and Opinion 1/92 Draft agreement between the Community, on the one hand, and the countries of the European Free Trade Association, on the other, relating to the creation of the European Economic Area [1992] ECR I2821.

87 Ott (n 48) 130.

88 Opinion 1/92 (n 86) para 6.

89 Ott (n 48) 130.

90 For example, a decision issued by the respective EU institution binding within the EU, but not for the third county concerned.

91 Ott (n 48) 131-132.

92 ibid.
} 
involved in the board of EU agencies normally have a limited status, excluding participation in the adoption of final decisions. ${ }^{93}$

Looking at the participation of candidates and potential candidates in EU agencies in the broad sense - ie in the form of technical assistance and projects carried out by the latter in the framework of EU programmes - it appears that the principle of institutional balance is not breached. First, because such technical assistance and projects reflect a rather classical Meroni scenario involving delegation from the Commission to EU agencies under EU Financial regulations. ${ }^{94}$ In this context, the Commission (DG Enlargement) defines, finances, and supervises the project, while EU agencies only carry out the required implementing actions. Second, because such technical assistance is carried out by EU agencies in view of their expertise and, therefore, it is normally confined to their respective mandate as defined by their respective founding acts. Third, because such technical assistance usually does not materialise in legally binding instruments, but in rather informal actions or soft law instruments which are not perceived as encroaching upon the powers of EU institutions or causing other significant legal problems. This conclusion also applies to other technical assistance activities carried out on an ad hoc basis or in informal settings such as various networks, provided that such assistance falls within the mandate of the respective agency, as defined by its relevant legal framework.

Likewise, the involvement of EU agencies in the monitoring process of candidate and potential candidate countries does not seem legally problematic. Thus, the Commission involves the EU agencies in the monitoring process by establishing their precise role and ensuring oversight over their actions. Furthermore, such inspection and monitoring tasks come within the mandate of these bodies via their founding acts or in the framework of the agreements concluded between the Union and the candidate and potential candidate countries with a view to their accession. Finally, the monitoring activities performed by EU agencies do not entail direct legal consequences as such. They result in reports that are forwarded to the Commission; it is then up to the Commission to take the necessary actions, including legally binding decisions.

Conversely, the formalised cooperation instruments concluded by some EU agencies with candidate and potential candidate countries entail international law implications and raise difficulties in terms of the

\footnotetext{
93 ibid 133.

94 See Article 13 (4) of Council Regulation (EC) 1085/2006 of 17 July 2006 establishing an Instrument for Pre-Accession Assistance (IPA) [2006] OJ L210/82 with the latest amendments, as well as Article 54 (2) of Council Regulation (EC, Euratom) 1605/2002 (n 79).
} 
principle of institutional balance. ${ }^{95}$ The reason for this is that the agreements or arrangements concluded by some EU agencies might turn out to be legally binding agreements or, otherwise, entail some legal consequences under international law. ${ }^{96}$ This triggers two important legal questions. First, how can one determine the legal nature and effects of the formalised international cooperation instruments concluded by EU agencies? Second, is it permissible to entrust these bodies with such prerogatives under the current EU legal and institutional framework?

Regarding the legal nature of such formalised cooperation instruments, no general conclusions can be drawn. ${ }^{97}$ Instead, a case-by-case analysis on the basis of relevant criteria needs to be performed for each instrument or category of instruments concluded by each EU agency. Such criteria include the wording and substance of the instrument, as well as the particular circumstances (context) in which the instrument has been negotiated, concluded and implemented. ${ }^{98}$ While the agreements concluded by Europol could arguably be qualified as binding international agreements, a different conclusion seems to apply in the case of Frontex, whose working arrangements specify that they are not to be considered as international treaties. ${ }^{99}$ However, even if such agreements or arrangements can be qualified as 'nonbinding' or 'soft law instruments', they might still entail some legal effects in international law. ${ }^{100}$ Based on the assumption that such agreements, even if not legally binding, might contain, nevertheless, 'undertakings taken seriously' by the parties, ${ }^{101}$ it follows that they might trigger the application of the estoppel principle (based on 'expectations of continued observance by the parties'). ${ }^{102}$ In this context, one should add that soft law instruments are

95 See Ott (n 2).

96 On the issue of the legal effects that non-binding agreements could entail, see O Schachter, 'The Twilight Existence of Nonbinding International Agreements' (1977) 71(2) American Journal of International Law 303.

97 Ott (n 2) 535-538.

98 At least, this is the position of the International Court of Justice (ICJ) in Maritime Delimitation and Territorial Questions between Batar and Bahrain, Jurisdiction and Admissibility, Judgment, ICJ Reports 1994, 112 and Aegean Sea Continental Shelf, Judgment, ICJ Reports 1978, 3. See also Schachter (n 96) 297; HG Schermers and NM Blokker, International Institutional Law. Unity Within Diversity (4 ${ }^{\text {th }}$ rev edn, Martinus Nijhoff Publishers 2003) 1112 1113. It should be added that the Court of Justice of the European Union (CJEU) took a similar view on this matter. See Case C-233/02 France $v$ Commission [2004] ECR I-2759, para 40; Case C-327/1991 France v Commission [1994] ECR I-3641, para 15.

99 Ott (n 2) 535-536. See also Ott (n 48) 133.

100 Schachter (n 96) 303. Furthermore, the mere fact that such instruments have a soft law or non-binding nature does not necessarily imply that EU agencies are always competent to adopt them. See Case C-233/02 France v Commission (n 98) para 40.

101 Schachter (n 96) 303.

102 ibid 304. 
said to be legally relevant, in particular when they contain (administrative) 'rules and technical standards' for the implementation of treaties and other binding international instruments. ${ }^{103}$

As regards the issue of whether EU agencies can actually use such international cooperation instruments according to EU law, the following preliminary observations can be advanced. Thus, one may argue that, even in the absence of an express provision to that effect in the founding treaties, these bodies could, in principle, be equipped with such (functional) external powers via their founding acts and other secondary law instruments. ${ }^{104}$ This is legally acceptable provided that such prerogatives are sufficiently defined and do not entail a significant degree of discretion. Furthermore, supervision over the exercise of such prerogatives must be ensured to the extent that the balance of powers in the area of EU external relations is maintained. ${ }^{105}$ Accordingly, EU agencies can exercise international cooperation prerogatives as long as this is authorised explicitly or implicitly by their legal framework and provided that such prerogatives are limited by and instrumental to the EU agencies' mission and objectives. An important validating factor, especially when the founding acts do not include (detailed) provisions on international cooperation tasks and instruments, is supposedly acceptance by the main EU institutions of the instruments enacted by EU agencies in practice. ${ }^{106}$

Arrangements of a soft law nature concluded by EU agencies with candidates and potential candidates would not be so problematic, since they are not likely to be perceived as encroaching upon the powers of EU institutions. ${ }^{107}$ Conversely, if some of these instruments are binding international agreements, objections based on the particular balance of powers established by the founding treaties with regard specifically to EU treaty-making can still be raised. ${ }^{108}$ This seems to be the case because of the (strict) stance admittedly taken by the CJEU with regard to this issue. ${ }^{109}$ According to the Court, the founding treaties set up a particular balance of powers with regard to formal EU treaty-making. Thus, com-

\footnotetext{
103 AE Boyle, 'Some Reflections on the Relationship of Treaties and Soft Law' (2001) 48(4) ICLQ 905. See also L Senden, 'Soft Law in European Community Law. Its Relationship to Legislation' (DPhil thesis, Tilburg University 2003) 106.

104 Including international agreements concluded by the EU.

105 This would further imply that formal agreements and arrangements concluded by EU bodies could be attributed also to the EU. Cf Ott (n 2) 539-540.

106 So far, in practice, EU agencies' international cooperation tasks and instruments do not seem to have encountered significant opposition from the main EU institutions.

107 Cf Case C-233/02 France $v$ Commission (n 98) paras 40-45.

108 See, for details, Ott (n 2).

109 See Case C-327/1991 France $v$ Commission (n 98) and Case C-233/02 France $v$ Commission (n 98).
} 
petence to conclude treaties on behalf of the Union lies with the Council, while the Commission, ${ }^{110}$ in principle, initiates the treaty-making procedure and is heavily involved in the negotiation process. ${ }^{111}$ From this, one could infer that binding international agreements concluded by EU agencies, as well as the provisions in their founding acts providing for such instruments, are incompatible with the balance of powers established in Article 218 TFEU with regard to EU treaty-making. However, in the international law literature it is maintained that the organs competent to conclude agreements on behalf of an international organisation can, in principle, delegate their prerogatives to other organs or bodies if this is not explicitly or implicitly prohibited by the constitution of the organisation. ${ }^{112}$ Referring now to the EU context, while the Court emphasises the particular balance of powers with regard to EU treaty-making, it seems, however, that the CJEU does not read in the founding treaty that there is an absolute prohibition of delegating such prerogatives to other EU institutions and bodies. As suggested by Advocate General Alber with regard specifically to the Commission's capacity to conclude agreements, the balance of powers with regard to treaty-making does not mean that the Council could never delegate such power and that the Commission could never conclude an agreement. ${ }^{113}$ This would rather mean that the power of the Commission to conclude agreements is specific and must necessarily flow from the powers conferred by the Council. ${ }^{114}$ By extending this reasoning to EU agencies, limited prerogatives could be delegated to these bodies ${ }^{115}$ by an act of secondary legislation emanating from

\footnotetext{
110 After the entry into force of the Lisbon Treaty, the High Representative is also involved in this process.

111 See Article 218 TFEU.

112 See H Chiu, The Capacity of International Organisations to Conclude Treaties, and the Special Legal Aspects of the Treaties so Concluded (Martinus Nijhoff 1966) 89-90.

113 See Case C-233/02 France $v$ Commission (n 98) Opinion of AG Alber delivered on 25 December 2003, para 71 .

114 ibid.

115 One may wonder though whether such delegation should always be explicit or whether it could also result from more general provisions on international cooperation or from the way in which the objectives and functions of the agency are designed. This would very much depend on how the requirement regarding the sufficiently defined and non-discretionary nature of the powers conferred on EU agencies is read. While explicit provisions with regard to the prerogative of EU agencies to conclude international cooperation instruments would certainly help alleviating legal concerns, in other instances, objections can be raised as to the international dimension of the mandate of the agency. As already discussed, a solution would be a more flexible reading of the Meroni requirements founded on a functional approach, deriving the international cooperation prerogatives of the respective agency from its overall aims and functions. However, it is not sure whether the CJEU would be willing to embrace such a solution, considering the view taken in its previous case law with regard to the external powers of the Commission. See Case C-327/1991 France $v$ Commission (n 98) and Case C-233/02 France v Commission (n 98).
} 
the main EU institutions (the Council, the European Parliament, and the Commission) to conclude binding international agreements inherent to the fulfilment of their mandate and subject to appropriate supervision mechanisms. ${ }^{116}$ Such instruments concluded by EU agencies would qualify as 'administrative agreements'117 or as 'agreements for technical cooperation' - a category acknowledged as such in the international legal literature and practice, though still subject to controversy ${ }^{118}$ - and could be in line with the present-day requirements of institutional balance and delegation of powers. ${ }^{119}$

\section{The case of the European Aviation Safety Agency (EASA)}

\subsection{The legal and policy background}

The involvement of the European Aviation Safety Agency (EASA) in the process of enlargement needs to be linked to the policy, legal and institutional context of its area of operation. ${ }^{120}$ EASA became operational in 2003 in an environment 'replete' with organisations and bodies at all levels - international (International Civil Aviation Organisation - ICAO), European (Eurocontrol), the EU (Commission) and Member States, as well as third countries (national aviation authorities). ${ }^{121}$ The agency itself was built upon the pan-European Joint Aviation Authorities (JAA), an informal network entrusted with standardisation and inspection tasks embracing the national aviation authorities of most European countries. ${ }^{122}$

116 Obviously, the EU agencies cannot claim general power to conclude legally binding agreements with non-EU actors based merely on their internal powers.

117 See J Klabbers, 'The Concept of Treaty in International Law' (DPhil thesis, University of Amsterdam, Kluwer Law International 1996) 97-108.

118 See Chiu (n 112) 122-138 and 168-177; HG Schermers and NM Blokker, International Institutional Law: Unity Within Diversity ( $5^{\text {th }}$ rev edn, Martinus Nijhoff Publishers 2011) 1139-1149.

119 The agreements concluded by Europol, Eurojust, and Cepol seem to reflect a Meronilike scenario because such powers are conferred by a Council decision (founding act). Furthermore, the exercise of these prerogatives by the respective agencies is subjected to the Council's supervision and control (see Article 23 of the Europol founding decision; Article $26 \mathrm{a}$ of the Eurojust founding decision; Article 8 of the Cepol founding decision). Cf Ott (n 2) 539-540.

120 See generally on the transport sector in the context of the enlargement process, V Kronenberger 'Transport' in Ott and Inglis (n 28) 965-995.

121 See M Groenleer 'Linking up Levels of Governance: Agencies of the European Union and their Interaction with International Organisations' in O Costa and K-E Joergensen (eds), The Influence of International Institutions on the European Union (Palgrave Macmillan 2012) 135.

122 See A Schout 'Inspecting Aviation Safety in the EU: EASA as an Administrative Innovation?' in E Vos (ed), European Risk Governance: Its Science, its Inclusiveness and its Effectiveness (Connex Report Series Nr 06, 2008) 266-270. JAA was an associate body of the European Civil Aviation Conference (ECAC), representing the civil aviation regulatory 
In this context, EASA has been equipped with regulatory, certification and standardisation tasks in the EU aviation safety area. ${ }^{123}$ As a result, by way of a Protocol to the so-called 'Cyprus Arrangements', ${ }^{124}$ EASA has been involved in the JAA with a view to preserving 'the pan-European dimension of Civil Aviation safety and environmental protection regulation'. ${ }^{125}$ Within this framework, EASA has been enabled to coordinate the work of the aviation authorities of the Member States, to represent them on matters within EU exclusive competence, and to cooperate with JAA authorities not subject to the EASA Regulation. ${ }^{126}$

These developments should be seen as part of the overall EU external aviation policy strategy aimed at creating a European Common Aviation Area. The Common Aviation Area is intended to become ultimately a single pan-European air transport market, based on a common set of rules applicable to the EU and its neighbours. ${ }^{127}$ In this framework, the EU perceives itself as the main institutional and regulatory driver, implying that the non-EU participant countries should progressively adopt the Union's standards and rules. ${ }^{128}$ In furthering this policy aim, the EU

authorities of a number of European States who had agreed to cooperate in developing and implementing common safety regulatory standards and procedures. This cooperation was intended to provide high and consistent standards of safety and a 'level playing field' for competition in Europe. JAA officially ended on 30 June 2009 and has been replaced gradually by working arrangements concluded between EASA and national aviation authorities from European countries that are not members of the EU with a view to ensuring the panEuropean dimension of aviation safety. See JAA, <http://www.jaa.nl/introduction/introduction.html>; for a concrete illustration, see the Preamble to the Working Arrangement between EASA and the Croatian Civil Aviation Agency, signed on 7 July 2009 <http://easa. europa.eu/rulemaking/docs/international/croatia/WA\%20CROATIA.pdf>.

123 M Groenleer, M Kaeding, and E Versluis 'Regulatory Governance through Agencies of the European Union? The Role of the European Agencies for Maritime and Aviation Safety in the Implementation of European Transport Legislation' JEPP (17) 1221. See also the Preamble to EASA's initial founding act - Regulation (EC) 1592/2002 of the European Parliament and of the Council of 15 July 2002 on common rules in the field of civil aviation and establishing a European Aviation Safety Agency [2002] OJ L240/1.

124 Arrangements concerning the Development, the Acceptance and the Implementation of Joint Aviation Requirements, concluded in Cyprus on 11 September $1990<$ https://easa. europa.eu/rulemaking/docs/international/archive/cyprus.pdf>.

125 Recital (3) of the Preamble of the Protocol to the Cyprus Arrangements on the Participation of the European Aviation Safety Agency, concluded on 25 November 2003

$<$ http://easa.europa.eu/rulemaking/docs/international/archive/Protocol_Cyprus.pdf > .

126 See Articles 4-6 of the Protocol to the Cyprus Arrangements (n 125).

127 See Commission (EC), 'A Community aviation policy towards its neighbours' (Communication) (2004) 74 final. See also Commission (EC), 'Developing the agenda for the Community's external aviation policy' (Communication) (2005) 79 final and Commission (EC), 'Common aviation area with the neighbouring countries by 2010 - progress report' (Communication) (2008) 596 final.

128 See COM (2004) 74 (n 127) 6. See also COM (2005) 79 (n 127), COM (2008) 596 (n 127), and the information note on the ECAA posted on the website of the European Commission, in the section 'International Aviation - ECAA' <http://ec.europa.eu/transport/air/inter- 
and its Member States concluded in 2006 an Agreement on the establishment of a European Common Aviation Area (ECAA) ${ }^{129}$ with several European countries, ${ }^{130}$ with further negotiations on the way for other countries, including Turkey, to join the system. ${ }^{131}$

In this context, EASA serves as an instrument designed to contribute to the fulfilment of ECAA. Thus, EASA provides assistance to non-EU states with regard to EU aviation standards and integrates the competent aviation authorities from such countries into its own system. Moreover, EASA is monitoring the process of alignment and implementation by these countries of the relevant EU legislation. ${ }^{132}$ It is also from this specific angle that EASA's relations with candidate and potential candidate countries should be viewed.

\subsection{The involvement of EASA in the enlargement process}

To begin with, EASA's founding regulation provides explicitly for participation in the agency (including the management board) by European third countries that have entered into agreements with the EU and that apply EU aviation law. ${ }^{133}$ For candidate and potential candidate countries specifically, ${ }^{134}$ participation in the work of EASA is further stipulated in the ECAA agreement. ${ }^{135}$ As a result, the management board of EASA now includes observers from Albania, Bosnia and Herzegovina, Croatia, the Former Yugoslav Republic of Macedonia, Montenegro, and Serbia. ${ }^{136}$

national_aviation/country_index/doc/information_note_ecaa.pdf> last updated 9 October 2012.

129 Multilateral Agreement between the European Community and its Member States, the Republic of Albania, Bosnia and Herzegovina, the Republic of Bulgaria, the Republic of Croatia, the former Yugoslav Republic of Macedonia, the Republic of Iceland, the Republic of Montenegro, the Kingdom of Norway, Romania, the Republic of Serbia and the United Nations Interim Administration Mission in Kosovo on the establishment of a European Common Aviation Area [2006] OJ L285/3, also referred to in this paper as the 'ECAA agreement'.

130 These include current candidate and potential candidate countries, except for Turkey.

131 See COM (2008) 596 (n 127).

132 See, for instance, the Preamble to the Working Arrangement between the European Aviation Safety Agency and the Croatian Civil Aviation Agency (n 122).

133 Articles 34 (2) and 66 of EASA's founding regulation (n 14).

134 Except for Turkey.

135 See, in particular, Annex V of the ECAA agreement (n 129).

136 See EASA's Annual Report 2010, 50 <http://easa.europa.eu/management-board/ docs/management-board-meetings/2011/02/EASA\%20MB\%20Decision\%2005-2011\%2 0Adopting\%20the\%202010\%20Annual\%20General\%20Report\%20ANNEX\%201.pdf> and EASA's Annual Report $2011<$ http://easa.europa.eu/communications/docs/annual-report/EASA-Annual_Report_2011.pdf>. See also EASA <http://easa.europa.eu/management-board/management-board.php>. 
Special mention should be made of Croatia, since it became an 'acceding country' as of December 2011. Accordingly, Croatia's representatives in EASA's management board should currently have the status of 'active observer', entailing active participation in the activities and meetings of this body, except for the right to participate in the adoption of final decisions. Iceland is a special case, as it is granted the status of member of EASA's management board, but without voting rights. ${ }^{137}$ While in all cases a candidate or potential candidate country is not directly involved in decision-making, there is, however, a differentiation between the Western Balkan countries (except for Croatia) and Iceland. Thus, in the latter case, participation in the management board entails more than passive observation, but also the possibility to take an active stance through the right to speak, make observations, etc. As an 'acceding country', Croatia should have a position similar to that of Iceland. One may conclude that EASA is an exemplary EU agency, since participation in the management board by most candidate and potential candidate countries to EU accession is activated. As regards the degree of participation in the management board, this does not seem to deviate from the standard model applied within other EU agencies.

As far as technical assistance to candidate and potential candidate countries is concerned, EASA's actions seem to remain within the general blueprint entailed by this form of EU agencies' involvement. Thus, according to its own activity reports, EASA has contributed mainly to defining and implementing various assistance projects and programmes involving candidate and potential candidate countries. More specifically, EASA provides support to the Commission in defining relevant European assistance projects and managing EU programmes. ${ }^{138}$ In this context, EASA also manages directly assistance projects and programmes for candidate and potential candidate countries with a view to ensuring familiarisation with and implementation of EU aviation rules, as well as the full integration of the aviation authorities of such countries in the EASA system. For instance, EASA managed a dedicated assistance programme for the Balkan countries under a convention signed with the European Commission Directorate for Enlargement as part of the CARDS programme. ${ }^{139}$ Another recent example is the involvement of EASA in the IPA multi-beneficiary programmes on preparatory measures for the par-

\footnotetext{
137 EASA's Annual Report 2010 (n 136) 50 and EASA's Annual Report 2011 (n 136) 106. A similar status is granted to the other EEA countries that are not members of the EU and to Switzerland.

138 See EASA's Annual Report 2010 (n 136) 64.

139 EASA's Annual Report 2008, 29 <http://easa.europa.eu/management-board/docs/ management-board-meetings/2009/02/EASA\%20MB\%20Decision\%2005-2009\%20Annex\%201\%20-\%202008\%20Annual\%20General\%20Report.pdf>.
} 
ticipation of candidate and potential candidates in EU agencies. ${ }^{140} \mathrm{Un}-$ der this programme, EASA receives a direct grant from the Commission to carry out various preparatory measures such as training activities, workshops, and outreach actions. By the same token, EASA also organises technical assistance missions in candidate and potential candidate countries $^{141}$ and other assistance activities to support the aviation authorities from these countries to improve their expertise. ${ }^{142}$

This overview of EASA's technical assistance activities in the context of enlargement reveals overall consistency with the Meroni logic. Thus, EASA's actions really seem limited to technical support and implementing activities and do not normally materialise in legally binding acts. Such activities seem to correspond to the role and tasks of the agency as specified in the founding regulation and other relevant legal instruments. With regard specifically to the assistance actions performed within the framework of EU programmes, these entail clear delegation from and supervision by the Commission.

As concerns the monitoring process of the progress of candidates and potential candidates in transposing and implementing the relevant EU acquis, EASA has admittedly an important say. This is linked to EASA's standardisation tasks derived from the JAA system, consolidated inter alia via the ECAA agreement and grounded in the founding regulation of EASA. ${ }^{143}$ Such tasks entail monitoring the implementation of EU legislation ${ }^{144}$ both by the Member States and by relevant third countries (including ECAA countries). The standardisation process includes inspection visits in the relevant countries and is materialised in reports that are also forwarded to the Commission. ${ }^{145}$ With regard specifically to candidate and potential candidates for accession, ${ }^{146}$ it is important to note that EASA has concluded working arrangements with the competent aviation authorities comprising provisions that pertain to the manner in which EASA oversees the implementation of the relevant EU legislation in these countries. Linking this with the monitoring process in the context of enlargement, it should be noted that the periodic progress reports released by the Commission on candidates and potential candidates also

\footnotetext{
140 See Project Fiche No 14 'Participation in EU Agencies' (n 53) 3-5.

141 See EASA's Annual Report 2010 (n 136) 64-65.

142 ibid 35.

143 See Article 24 of EASA's founding regulation (n 14).

144 As stipulated by EASA's founding regulation (n 14).

145 See Commission Regulation (EC) 736/2006 of 16 May 2006 on working methods of the European Aviation Safety Agency for conducting standardisation inspections [2006] OJ L129/10.

146 Including Turkey.
} 
cover the air transport policy area. More specifically, such reports usually include specific findings concerning the positive results and existing problems with regard to the implementation of EU standards in the aviation area. ${ }^{147}$ An example illustrating the impact that the monitoring tasks performed by EASA may have in the enlargement process is the notorious 'Bulgarian' case. In this case, the Commission invoked a 'safeguard clause' against Bulgaria in 2006, following a negative inspection report prepared by EASA, stating that Bulgaria had not been able to ensure full compliance with EU rules on aviation safety. ${ }^{148}$ As a result of the activation of the safeguard clause, Bulgaria was partially excluded from the benefits of the internal aviation market. ${ }^{49}$

However, EASA's monitoring and inspection tasks in relation to candidate and potential candidate countries seem not to cause problems as far as institutional balance and delegation of powers are concerned. Such tasks naturally derive from the external dimension of the EU aviation policy and are a necessary supportive element in the technicalities of the enlargement process. Besides, these tasks are enshrined in EASA's founding regulation and in other legal instruments (including international agreements and working arrangements). Last, the exercise of these tasks is materialised in non-binding instruments (ie reports), leaving to the Commission the required margin of (political) discretion to decide on the appropriate course of action.

Finally, as far as formalised cooperation instruments are concerned, it should be noted that EASA has concluded so far working arrangements with more than 30 third countries, including candidate and potential candidate countries. ${ }^{150}$ The possibility for EASA to use such formalised cooperation instruments is explicitly provided for in the agency's founding regulation. ${ }^{151}$ Furthermore, one should not overlook that the

\footnotetext{
147 For example, Commission (EC) 'Bosnia and Herzegovina 2010 Progress Report' (n 65) 49.

148 Commission (EC) 'Monitoring report on the state of preparedness for EU membership of Bulgaria and Romania' (Communication) COM (2006) 549 final, 26 September 2006, 12 and Commission Regulation (EC) 1962/2006 of 21 December 2006 in application of Article 37 of the Act of Accession of Bulgaria to the European Union [2006] OJ L408/8. See also Spernbauer (n 28) 286; Groenleer, Kaeding, and Versluis (n 123) 1224; and the European Commission's press release, 'European Commission Invokes Safeguard Clause against Bulgaria on Aviation Safety' (IP/06/1860, 20 December 2006) <http://europa.eu/rapid/pressReleasesAction. do? reference $=I P / 06 / 1860 \&$ type $=H T M L \&$ aged $=0$ \&language $=E N \&$ guiLanguage $=e n>$.

149 See Commission Regulation (EC) 1962/2006 (n 148). See also the European Commission's press release (n 148).

150 According to the information available on the official website of EASA in the section 'International Cooperation - Working Arrangements' <http://easa.europa.eu/rulemaking/ international-cooperation-working-arrangements.php>.

151 Article 27 of EASA's founding regulation (n 14).
} 
working arrangements concluded by EASA with the competent authorities from candidate and potential candidate countries are also to be seen as implementing tools of a wider international framework, including the ECAA and EEA agreements and the European Civil Aviation Conference (ECAC). One should further add that, as a rule, ${ }^{152}$ EASA has concluded two types of working arrangements with the competent authorities from candidates and potential candidates: (1) on the collection and exchange of information on aircraft safety to implement the Safety Assessment of Foreign Aircraft (SAFA) Programme, ${ }^{153}$ and (2) on regulatory cooperation and standardisation, in the context of the transition from JAA to the EASA system. ${ }^{154}$

As far as the legal nature of the working arrangements concluded by EASA is concerned, it is difficult to provide a straightforward answer. A closer look at some of these instruments reveals a rather mixed picture. Thus, the use of the word 'arrangement' instead of 'agreement' would suggest a non-binding instrument. ${ }^{155}$ In addition, the working arrangements regarding regulatory cooperation and standardisation usually include a similar clause stating that they '(...) do not affect or limit in any way the rights and obligations stemming from the relevant provisions of the ECAA Agreement'. ${ }^{156}$ On this basis, one might tentatively conclude that such arrangements are not binding international agreements.

However, other elements of the same instruments perhaps point to a different conclusion. In particular, the provisions regarding the standardisation procedure, the liaison activities, the entry into force as well as

152 The exception is Iceland, whose competent aviation authority has only concluded a working arrangement on collection and exchange of information on aircraft safety. See EASA <http://easa.europa.eu/rulemaking/international-cooperation-working-arrangements.php>.

153 Initially developed by the European Civil Aviation Conference (ECAC), SAFA was transferred to the EU by Directive (EC) 2004/36 of the European Parliament and of the Council of 21 April 2004 on the safety of third-country aircraft using Community airports [2004] OJ L143/76 (the so-called 'SAFA Directive'). See, for instance, Commission (EC), 'Report from the Commission on the European Community SAFA Programme (Safety Assessment of Foreign Aircraft)' [2008] OJ C42/1 and the information fiche 'The EC SAFA Programme: Past, Present and Future' <http://ec.europa.eu/transport/modes/air/safety/doc/2009_12_04_ info_fiche_safa_programme.pdf> last updated 9 October 2012.

154 See EASA <http://easa.europa.eu/rulemaking/international-cooperation-working-arrangements.php>.

155 However, in international law, the label of the instrument alone is not considered as sufficient evidence for supporting a conclusion regarding the legal nature of the respective instrument. See A Aust, Modern Treaty Law and Practice (Cambridge University Press 2003) 20-24; Klabbers (n 117) 68-72.

156 For example the Working Arrangement concluded with the Directorate General of Civil Aviation of the Republic of Albania, signed on 7 July 2009, 6 <http://easa.europa.eu/rulemaking/docs/international/albania/WA\%20ALBANIA.pdf>; the Working Arrangement concluded with the Croatian Civil Aviation Agency (n 122) 6. 
the amendment and termination procedure suggest that such working arrangements might contain legally binding commitments. ${ }^{157} \mathrm{~A}$ similar conclusion could also be advanced with regard to the working arrangements pertaining to information exchange, all the more so as these instruments also contain rather precise implementing actions and confidentiality duties for the parties. Moreover, unlike the first category, such arrangements do not include an explicit clause limiting their legal effects. But even with regard to the 'limiting' clause included in the working arrangements on regulatory cooperation and standardisation, one may argue that this does not necessarily deny any legal effects of such instruments. It rather clarifies that such working arrangements are implementing tools of a basic international agreement and, as a result, they must comply with the latter. ${ }^{158}$ Finally, the use in the working arrangements concluded by EASA of a treaty-like language such as the parties 'have agreed as follows' or the parties 'shall'159 is another factor pointing to a binding international agreement. All these elements seem to indicate the intention of the parties to create legally binding obligations. ${ }^{160}$

In sum, the legal nature of the working arrangements concluded by EASA with third countries, in general, and with candidate and potential candidate countries, in particular, is not entirely clear. While the qualification of these arrangements as soft law cooperation instruments would probably avoid difficult legal discussions, not the same thing can be said about the finding that some of EASA's formalised cooperation instruments could actually qualify as binding international agreements.

First, one may suspect that the principle of institutional balance is breached, since treaty-making is reserved for the institutions mentioned in Article 218 TFEU. ${ }^{161}$ However, as already discussed, while the CJEU emphasises the importance of the principle of institutional balance in the context of EU treaty-making, it seems that the Court does not necessarily read in the founding treaties that there is an absolute prohibition to delegate such prerogatives to other EU institutions and bodies. Provid-

\footnotetext{
157 Cf Ott (n 2) 535-538.

158 To that effect, this would actually equate with a confirmation of the legal effects of this category of working arrangements.

159 This applies, in particular, to the confidentiality clauses in the working arrangements pertaining to information exchange.

160 To put it more simply, as long as a cooperation instrument has the form and content of a treaty, one may presume its legal character as an international agreement. Cf Chiu (n 112) 209-212, also quoting the opinion of Judge Lauterpacht in his second report on the Law of treaties. Or, as Klabbers puts it, as soon as it becomes clear that an instrument is concluded with a view to creating commitments between the parties under international law, it constitutes an international agreement. See Klabbers (n 117) 249-250.
}

161 Ott (n 2) 535-538. 
ed that this delegation scenario is applicable also to EU agencies, several requirements would need to be fulfilled in accordance with the presentday understanding of the Meroni doctrine. Thus, international cooperation prerogatives, including powers to conclude international agreements must be: 1 . conferred by the main institutions via the founding act and other relevant legal instruments; 2 . strictly circumscribed to the mandate of the agency, and; 3 . subject to appropriate supervision. This seems to be the case with the working arrangements concluded by EASA because these are explicitly authorised by the agency's founding act and their scope is strictly limited to technical cooperation activities which come within the mandate of the agency. Furthermore, EASA's working arrangements are subjected to the Commission's prior approval. ${ }^{162}$ This alleviates the concerns regarding oversight over EASA's actions, but also implies that EASA could be considered as acting on behalf of the EU when concluding arrangements with candidate or potential candidate countries. ${ }^{163}$

Second, the finding that (some of) the working arrangements concluded by EASA with candidates to EU accession may contain binding commitments triggers important practical and legal consequences. ${ }^{164}$ If some EU agencies can conclude internationally binding instruments, it follows that such bodies are subject to legal obligations and that they can be held liable at the international level for the non-fulfilment of their duties. This could ultimately lead to the EU as such being bound by such commitments entered into by EU agencies and being held internationally liable, ${ }^{165}$ provided that these bodies act as EU 'agents'. Such a conclusion would apply to EASA as well, because the agency, while concluding working arrangements on its own behalf, can hardly be assumed to act independently as long as it must always obtain the Commission's approval.

\section{Conclusion}

This analysis reveals that, apart from the formalised cooperation instruments used by EU agencies, the forms in which these bodies partake in the process of enlargement are compatible overall with the EU legal framework. As far as the formalised cooperation instruments (arrangements, agreements, memoranda of understanding, etc) are concerned, these seem not to contravene the institutional balance and the

\footnotetext{
162 Article 27 of Regulation (EC) 216/2008 (n 14).

163 Cf Ott (n 2) 539-540.

164 ibid 534, 538-540.

165 ibid 540. Cf Klabbers arguing in a slightly different context that administrative agreements concluded by agencies become ultimately '(...) the onus of the state' (n 117) 103.
} 
delegation of power principles as long as they remain outside the realm of hard law and within the respective mandate of the agency. However, the finding that some of these instruments are legally binding triggers important consequences under international law. It further raises the question whether such 'agreements' would infringe the balance of powers laid down by the founding treaties between the institutions involved in the area of EU external action and, in particular, with regard to the Union's capacity to conclude international agreements. Objections against such 'empowerment' of EU agencies can be raised in particular in view of the rather conventional reading by the CJEU of the balance of powers between the EU institutions with regard to the Union's treaty-making. However, assuming that the Court does not institute an absolute prohibition to 'delegate' (limited) treaty-making prerogatives to other EU institutions and bodies, one can advance arguments for an 'escape route' based on a dynamic interpretation of the principle of institutional balance and of the delegation/conferment of power doctrine. According to this view, international cooperation prerogatives, including limited functional powers to conclude international agreements, may be conferred on EU agencies by the main EU institutions. Such prerogatives should be authorised via the founding acts of the agencies and other relevant instruments of secondary legislation, and they must be strictly circumscribed to the mandate of the agency, and subject to appropriate supervision by the relevant EU institutions.

Finally, what is questionable in legal theory seems to be accepted in daily reality, where, in spite of the use of such 'problematic' instruments by some EU agencies, no litigation has been initiated so far on this particular issue. This might indicate that recourse to such actions by EU agencies is not perceived as problematic in practice. On the contrary, it might be a response to some present-day practical needs within EU and global governance. 